
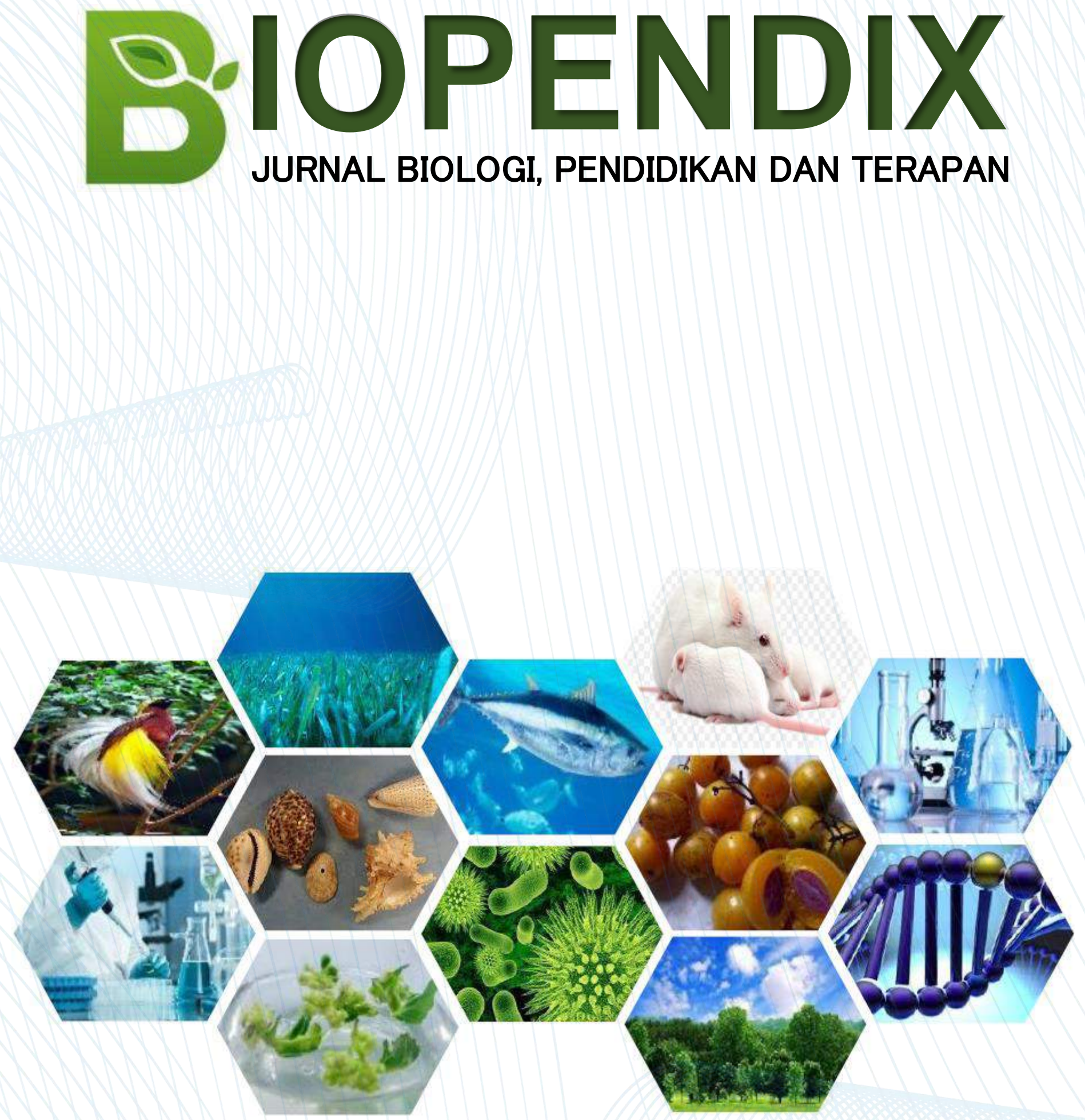

PUBLISHER BY:

BIOLOGY EDUCATION, UNPATTI AMBON - MALUKU 


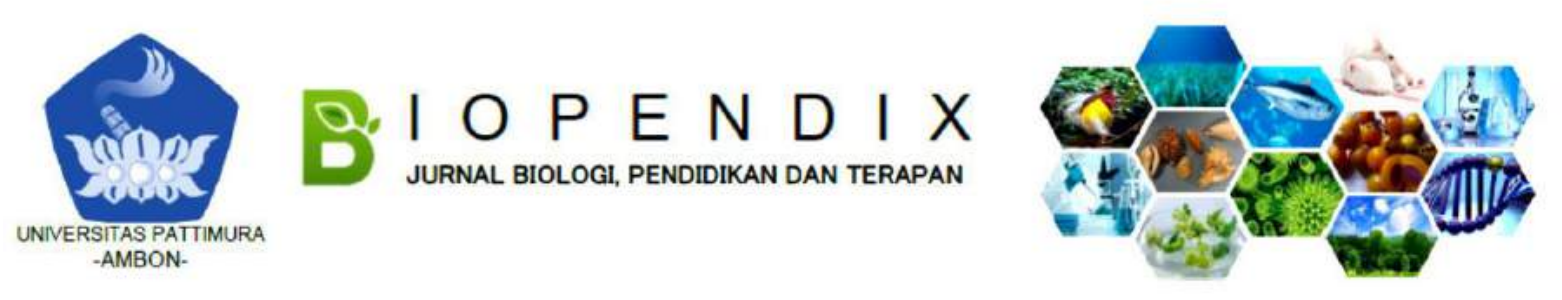

\title{
HUBUNGAN BAHAN AJAR EBOOK BERBASIS ANDROID DAN BERPIKIR KRITIS KONSEP SISTEM PERNAPASAN MANUSIA TERHADAP HASIL BELAJAR SISWA KELAS VIII SMP NEGERI 3 BULA
}

\author{
Siti Mia Soulissa1, Alwi Smith², M. Nur Matdoan² \\ ${ }^{1}$ Alumni Magister Pendidikan Biologi; ${ }^{2}$ Program Studi Magister Pendidikan Biologi \\ Corresponding author: Alwi Smith; E-mail: asmith.unpatti@gmail.com
}

\begin{abstract}
Background: This study aims to determine the relationship of e-book based teaching materials on Android and think critically to the learning outcomes of the concept of the human respiratory system.

Method: The type of research used is quase experimental research with one group pre-test post-test research design. This research was carried out at SMP Negeri 3 Bula on October 29, 2018 - November 29,2018 . The sample in this study was eighth grade students consisting of 22 people, data collection instruments in the form of learning outcomes tests and questionnaire sheets. Data were analyzed using correlation test with the help of SPSS Version 23.0 for windows.

Results: There is a very weak relationship of teaching materials based on android e-books on the learning outcomes of the concept of the human respiratory system with a correlation value -, 145 . There is a very weak relationship with learning outcomes with a correlation value $(r)$ of -104 . There is a very strong and significant relationship between teaching materials based on android e-books and critical thinking together on the learning outcomes of the concept of the human respiratory system with a correlation value $(r)$ of 0.971 .

Conclusion: Both variables have a very weak negative relationship. Critical thinking on learning outcomes has a very weak negative relationship. Critical thinking contributes to learning outcomes of $10.4 \%$ and the remaining $89.6 \%$ comes from other factors. There is a relationship between Androidbased Ebook teaching materials and critical thinking on learning outcomes.
\end{abstract}

Keywords: Android Based Ebook Teaching Material, Critical Thinking, Learning Outcomes

\begin{abstract}
Abstrak
Latar Belakang: Penelitian ini bertujuan untuk mengetahui hubungan bahan ajar e-book berbasis android dan berpikir kritis terhadap hasil belajar konsep sistem pernapasan manusia.

Metode: Jenis penelitian yang digunakan ialah quase eksperimental research dengan rancangan penelitian one group pre-test post-test. Penelitian ini di laksanakan pada SMP Negeri 3 Bula pada tanggal 29 Oktober 2018 - 29 November 2018. Sampel dalam penelitian ini siswa kelas VIII yang terdiri dari 22 orang, instrument pengumpulan data berupa tes hasil belajar dan lembar angket. Data dianalisis menggunakan uji korelasi dengan bantuan program SPSS Versi 23.0 for windows.

Hasil: Terdapat hubungan yang sangat lemah bahan ajar e-book berbasis android terhadap hasil belajar konsep sistem pernapasan manusia dengan nilai korelasi -,145. Terdapat hubungan yang sangat lemah terhadap hasil belajar dengan nilai korelasi ( $r$ ) sebesar -,104. Terdapat hubungan sangat kuat dan signifikan antara bahan ajar e-book berbasis android dan berpikir kritis secara bersama-sama terhadap hasil belajar konsep sistem pernapasan manusia dengan nilai korelasi ( $r$ ) sebesar 0,971.

Kesimpulan: Kedua variabel memiliki hubungan yang negatif sangat lemah. Berpikir kritis terhadap hasil belajar memiliki hubungan yang negatif sangat lemah. Berpikir kritis berkontribusi terhadap hasil belajar sebesar $10,4 \%$ dan sisanya sebesar $89,6 \%$ berasal dari faktor lain. Terdapat hubungan antara bahan ajar Ebook berbasis android dan berpikir kritis terhadap hasil belajar.
\end{abstract}

Kata Kunci: Bahan Ajar Ebook Berbasis Android, Berpikir Kritis, Hasil Belajar 


\section{PENDAHULUAN}

Pendidikan pada dasarnya merupakan interaksi atau komunikasi antara dua subjek pendidik dengan siswa untuk mencapai tujuan pendidikan yang berlangsung dalam lingkungan tertentu. Interaksi ini disebut dengan interaksi pendidikan, yaitu saling pengaruh antara pendidik dengan siswa (Sukmadinata, 2009). Pendidikan merupakan salah satu kebutuhan dalam kehidupan manusia. Pada UU Sisdiknas Nomor 20 tahun 2003 dijelaskan bahwa "manusia membutuhkan pendidikan dalam kehidupannya, pendidikan merupakan usaha agar manusia dapat mengembangkan poptensi dirinya melalui proses pembelajaran dan atau cara lain, yang dikenal dan diakui masyarakat.

Kualitas sumberdaya manusia di Indonesia dibandingkan dengan 174 negara di dunia tiap tahun mengalami penurunan (Fikri, 2011). Hal ini tersebut berdasarkan hasil survey yang dilakukan UNESCO pada tahun 2000 mengenai peringkat Indeks Pengembangan Manusia (Human Development Index), Indonesia menempati urutan ke-120 pada tahun 1996, ke-99 pada tahun 1997, ke-105 pada tahun 1998, dan ke-109 pada tahun 1999 yaitu, komposisi dari peringkat pencapaian pendidikan, kesehatan dan penghasilan per kepala yang menunjukan bahwa indeks pembangunan manusia Indonesia makin menurun. Dalam upaya menumbuhakan semangat dan motivasi belajar siswa, maka para guru diharuskan untuk dapat membuat pembelajarannya lebih menarik dan inovatif, sehingga siswa terdorong secara optimal dalam belajar baik secara individu, berkelompok maupun secara keseluruhan di dalam kelas.

Seiring dengan perkembangan zaman, seharusnya teknologi telah menyentuh level pengajaran di sekolah, namun jika dilihat TIK (teknologi, informasi dan komunikasi) dimana sebagai penunjang dalam proses pembelajaran belum dimanfaatkan dengan baik. Hal ini disebabkan oleh dua faktor, yaitu sarana sekolah dan sumber daya manusia (SDM) sebagai pengelolanya. Menurut (Drouin dkk, 2013) penggunaan teknologi tersebut akan memacu minat siswa untuk belajar karena dapat menjelaskan materi secara lebih jelas dan sesuai perkembangan anak pada era digital. Teknologi merupakan salah satu faktor yang dapat diperhitungkan dan mempengaruhi proses pembelajaran terutama perilaku siswa dalam belajar. Dengan kemajuan perangkat elektronik komputer, handphone, tablet dan lain sebagainya siswa dapat mengakses informasi dengan mudah dan lebih cepat.

Berkembangnya teknologi komputer dan digital guru haruslah bisa menggunakan dan memanfaatkan media untuk pembuatan bahan ajar untuk proses pembelajaran baik dalam kelas, individu, maupun berkelompok, namun pada kenyatanyaan guru lebih sering menggunakan metode konvensional. Dengan keadaan belajar seperti ini sering siswa mengalami kejenuhan dan sulit untuk menerima apa yang telah disampaikan oleh guru, akhirnya timbul keributan antara siswa yang satu dengan siswa yang lain dan adapula yang sibuk dengan handphone untuk mengakses media sosial, daripada mengakses suatu informasi yang berkaitan dengan pembelajaran. Dari pemaparan latar belakang di atas, maka perlu adanya strategi pembelajaran dengan menggunakan bahan ajar sesuai kebutuhan siswa, untuk itu peneliti mencoba menggunakan bahan ajar dalam pembelajaran yang menarik sesuai perkembangan zaman saat ini, dan bisa digunakan oleh siswa kapan saja, di mana saja dan bukan hanya pada jam pelajaran di sekolah, seperti bahan ajar ebook berbasis android.

SMP Negeri 3 Bula merupakan salah satu sekolah yang masih cenderung menggunakan bahan ajar yang hanya dimiliki oleh guru yaitu, buku paket dan proses pembelajaran yang masih konvensional, yaitu guru ceramah dan bertanya. Dalam proses pembelajaran yang terjadi hanyalah guru yang lebih aktif dalam arti guru yang memberikan materi dan memberikan pertanyan dan guru pula yang harus menjawab pertanyaanya sendiri. Sedangkan siswa dituntut untuk dapat memhami materi atau konsep yang disampaikan serta berinteraksi agar proses belajar mengajar lebih kreatif dan inovatif. Hal ini dikarena tidak ada bahan ajar atau media yang interaktif siswa hanya fokus tentang apa yang dituliskan pada papan tulis dan apa yang sampaikan oleh guru. 


\section{METODE}

Jenis penelitian yang digunakan adalah quasi eksperimental research, dengan rancangan penelitian one group pretest post-test seperti pada Tabel 1, dan perlakuan diberikan pada satu kelas untuk melihat ketuntasan hasil belajar melalui pretest dan post-test.

Tabel. 1 Desain penelitian

\begin{tabular}{cccc}
\hline Kelas & Pre-test & Perlakuan & Post-test \\
\hline VIII & $\mathrm{O}_{1}$ & $\mathrm{X}$ & $\mathrm{O}_{2}$ \\
\hline
\end{tabular}

Keterangan: O1: Tes pemahaman awal terhadap konsep sistem pernapasan manusia. $\mathrm{X}$ : Pembelajaran menggunakan bahan ajar e-book berbasis android. O2: Tes pemahaman akhir terhadap sistem pernapasan manusia.

Populasi dalam penelitian ini adalah seluruh siswa kelas VIII SMP Negeri 3 Bula yang terdiri dari satu kelas. Sampel dalam penelitian ini adalah kelas VIII yang ditentukan secara pusrposive sampling dengan jumlah siswa sebanyak 22 orang. Terdiri dari dua variabel bebas yaitu bahan ajar ebook berbasis android dan berpikir kritis dan satu variabel terikat hasil belajar. Teknik pengumpulan data menggunakan tes hasil belajar dengan instrument soal terdiri dari 10 soal pilihan ganda, 5 soal essay dan lembar angket respon siswa terhadap bahan ajar ebook berbasis android serta angket berpikir kritis. Uji prasyarat terdiri dari uji normalitas, uji homogenitas dan uji hipotesis yang dilakukan uji korelasi $(r)$ sederhana dan uji korelasi ( $r$ ) ganda dengan menggunakan bantuan program SPSS versi 23.0 for windows.

\section{HASIL DAN PEMBAHASAN Uji Prasyarat Analisis Uji Normalitas}

Pada uji normalitas peneliti menganalisis menggunakan uji chi square $\left(X^{2}\right)$ dengan melihat pada pengambilan keputusan apabila nilai sig. lebih besar dari nilai $\alpha$ atau (sig. > 0,05) maka data yang diperoleh berdistribusi normal ataupun sebaliknya. Hasil analisis uji normalitas dapat dilihat pada Tabel 2 di bawah ini.

Tabel 2. Hasil Uji Normalitas

\begin{tabular}{lrrrr}
\hline & \multicolumn{2}{c}{ Chi-Square Tests } & \\
\hline & \multicolumn{1}{l}{ Value } & df & $\begin{array}{c}\text { Asymptotic Significance } \\
(2-s i d e d)\end{array}$ & .156 \\
\hline Pearson Chi-Square & $122.833^{a}$ & 108 & .995 \\
\hline Likelihood Ratio & 74.275 & 108 & .014 \\
\hline Linear-by-Linear & 6.094 & 1 & \\
Association & 22 & & \\
\hline N of Valid Cases & 22 & & \\
\hline
\end{tabular}

a. 130 cells $(100.0 \%)$ have expected count less than 5 . The minimum expected count is. 05.

\section{Sumber Data: Data Primer}

Dari Tabel 2 di atas hasil output SPSS dari variabel terikat $Y$ (hasil belajar) yang terdiri dari pre-test dan post-test tersebut memliki nilai signifikan lebih besar dari nilai a $(0,156>0.05)$, maka dapat disimpulkan bahwa data berdistribusi normal.

\section{a. Uji Homogenitas}

Tujuan dari uji homogenitas untuk melihat apakah data-data dari variabel X1 (bahan ajar ebook berbasis android), X2 (berpikir kritis) dan $\mathrm{Y}$ (hasil belajar) yang didapat memiliki varians yang sama atau tidak, dengan mengacu pada pedoman kriteria sebagai berikut. 
1. Apabila nilai sig $>0.05$ maka data memiliki varians yang sama atau homogen.

2. Apabila nilai sig<0.05 maka data memiliki varians yang tidak sama atau tidak homogen.

Untuk mempermudah peneliti dalam menganalisis, peneliti menggunakan bantuan program IBM statistic SPSS versi
23.0 dan hasil analisis dapat dilihat pada Tabel 3 dan 4.

Uji Homogenitas Variabel Bebas Bahan Ajar Ebook Berbasis Android (X1), Berpikir Kritis (X2) dan Variabel Terikat Pre-test (Y).

Tabel 3. Hasil Uji Homogenitas X1, X2 dan Y (pretest)

\begin{tabular}{lrrrr}
\hline \multicolumn{5}{c}{ Test of Homogenity of Variances } \\
\hline & $\begin{array}{c}\text { Levene } \\
\text { Statistic }\end{array}$ & df1 & df2 & \multicolumn{1}{l}{ Sig. } \\
\hline Bahan Ajar Ebook & 2.986 & 6 & 12 & .050 \\
\hline Berpikir Kritis & 4.775 & 6 & 12 & .010 \\
\hline
\end{tabular}

\section{Sumber data: Data Primer}

Dari hasil bahan ajar ebook berbasis android dengan hasil belajar (pre-test) terdapat nilai sig. 0,050 maka data memiliki varians yang sama, kemudian berpikir kritis dengan hasil belajar (Pre-test) terdapat nilai sig. 0.010 dan dapat disimpulkan data yang diperoleh tidak memiliki varians yang sama atau tidak homogen.

Uji homogenitas Variabel bebas bahan ajar ebook berbasis android (X1), berpikir kritis (X2) dan variabel terikat posttest (Y)

Tabel 4. Hasil Uji Homogenitas X1, X2 dan Y (posttes)

\begin{tabular}{lcccc}
\hline \multicolumn{5}{c}{ Test of Homogenity of Variances } \\
\hline & Levene Statistic & df1 & df2 & Sig. \\
\hline Bahan ajar ebook & .721 & 5 & 9 & .624 \\
\hline Berpikir kritis & 1.419 & 5 & 9 & .305 \\
\hline
\end{tabular}

\section{Sumber Data: Data Primer}

Berdasarkan Tabel 4 hasil output uji homogenitas bahan ajar ebook berbasis android dan berpikir kritis dengan hasil belajar (posttes) dapat diketahui nilai sig. 0,624 dan 0,305 maka dapat ditarik kesimpulan data yang diperoleh memeliki varians yang sama atau homogen.

\section{Uji Hipotesis}

Setelah uji prasyarat selesai dan terpenuhi, selanjutnya akan dilakukan uji korelasi baik secara sederhana antara satu variabel bebas dengan variabel terikat dan korelasi ganda antara dua variabel bebas dengan variabel terikat secara bersamasama.

Untuk melihat tingkat keeratan hubungan antara variabel dengan mengacu pada tabel pedoman interpretasi nilai koefisien korelasi (r) di bawah ini.
Tabel 5. Interpretasi Koefisien Korelasi

\begin{tabular}{cc}
\hline Koefisien Korelasi & Tingkat Hubungan \\
\hline $0,00-0,199$ & Sangat Lemah \\
\hline $0,20-0,399$ & Lemah \\
\hline $0,40-0,599$ & Sedang \\
\hline $0,60-0,799$ & Kuat \\
\hline $0,80-1,000$ & Sangat Kuat \\
\hline
\end{tabular}

(Sugiyono, 2012)

Hipotesis dalam penilitian ini adalah sebagai berikut:

1. $\mathrm{H}_{0}$ : Tidak terdapat hubungan bahan ajar ebook berbasis android konsep sistem pernapasan manusia terhadap hasil belajar.

$\mathrm{H}_{\mathrm{a}}$ : Terdapat hubungan bahan ebook berbasis android konsep sistem 
pernapasan manusia terhadap hasil belajar.

2. $\mathrm{H}_{0}$ : Tidak terdapat hubungan berpikir kritis konsep sistem pernapasan manusia terhadap hasil belajar.

$\mathrm{H}_{\mathrm{a}}$ : Terdapat hubungan berpikir kritis konsep sistem pernapasan manusia terhadap hasil belajar.

3. $\mathrm{H}_{0}$ : Tidak terdapat hubungan bahan ajar ebook berbasis android dan berpikir kritis konsep sistem pernapasan manusia terhadap hasil belajar.
$\mathrm{H}_{\mathrm{a}}$ : Terdapat hubungan bahan ebook berbasis android dan berpikir kritis konsep sistem pernapasan manusia terhadap hasil belajar.

Analisis hubungan antara bahan ajar ebook berbasis android dengan hasil belajar

Besar hubungan anatara bahan ajar ebook berbasis android dengan hasil belajar dapat di lihat pada Tabel 6.

Tabel 6. Analisis Hipotesis Pertama

\begin{tabular}{|c|c|c|c|c|}
\hline \multicolumn{5}{|c|}{ Correlations } \\
\hline & & & $\begin{array}{c}\text { Bahan Ajar } \\
\text { Ebook }\end{array}$ & Post-test \\
\hline \multirow[t]{6}{*}{ Spearman's rho } & Bahan Ajar- & Correlation Coefficient & 1000 & -.145 \\
\hline & & Sig. (2-tailed) & . & .520 \\
\hline & & $\mathrm{N}$ & 22 & 22 \\
\hline & Post-test & Correlation Coefficient & -.145 & 1000 \\
\hline & & Sig. (2- tailed) & .520 & \\
\hline & & $\mathrm{N}$ & 22 & 22 \\
\hline
\end{tabular}

\section{Sumber data: Data Primer}

Berdasarkan hasil analisis hipotesis pertama yaitu uji korelasi sederhana pada Tabel 6 hubungan antara bahan ajar ebook berbasis android dengan hasil belajar konsep sistem pernapasan manusia terlihat nilai correlation coefficient -,145, dan dapat dikatakan kedua variabel memeliki hubungan yang negatif dan tingkat keeratannya sangat lemah.

Selanjutnya menghitung nilai $R$ (determinasi) untuk melihat seberapa (\%) distribusi bahan ajar ebook berbasis android terhadap hasil belajar 0,145 X 100\% = 14,5 dan sisanya $100 \%-14,5=85,5 \%$ dipengaruh oleh faktor lain maka, $\mathrm{Ha}$ diterima $\mathrm{H}_{0}$ ditolak. Menurut Usman (2000) indikator keberhasilan belajar adalah daya seraf siswa terhadap bahan pelajaran dan perilaku yang dilakukan individu maupun kelompok dalam mencapai tujuan pembelajaran.
Pada era digital sifat bahan ajar ebook berbasis android sangatlah fleksibel dan merupakan salah satu strategi yang mempermudah siswa dalam belajar. Alat komunikasi berstandar android ini sangatlah bersahabat dengan siswa sehingga dapat digunakan untuk mempelajari dan mengetahui masalah berupa konsep yang dipejari kapan saja, dimana saja baik di sekolah maupun di rumah tanpa waktu tertentu dan sumber bahan cetak lainnya. Bahan ajar ebook berbasis android juga dapat menjawab permasalahan seperti keterbatasan siswa dalam memperoleh buku-buku paket.

\section{Analisis hubungan antara berpikir kritis dengan hasil belajar}

Besar hubungan anatara berpikir kritis dengan hasil belajar dapat di lihat pada Tabel 7. 
Tabel 7. Analisis Hipotesis Kedua

\begin{tabular}{lllrr}
\hline & \multicolumn{2}{c}{ Correlations } & \multicolumn{1}{c}{$\begin{array}{c}\text { Bahan Ajar } \\
\text { Ebook }\end{array}$} & \multicolumn{1}{r}{ Post-test } \\
\hline \multirow{2}{*}{ Spearman's rho } & $\begin{array}{l}\text { Berpikir } \\
\text { Kritis }\end{array}$ & Correlation Coefficient & 1000 & -.104 \\
\cline { 3 - 5 } & & Sig. (2-tailed) &. & .646 \\
\cline { 2 - 5 } & N & -.104 & 22 \\
\cline { 2 - 5 } & Post-test & Correlation Coefficient & .646 & 1000 \\
\cline { 2 - 5 } & Sig. (2- tailed) & 22 & 22 \\
\cline { 2 - 5 } & $\mathrm{N}$ & & 22 \\
\end{tabular}

\section{Sumber Data: Data Primer}

Berdasarkan hasil analisis hipotesis kedua yaitu uji korelasi sederhana pada Tabel 2 hubungan berpikir kritis dengan hasil belajar konsep sistem pernapasan manusia dengan nilai correlation coefficient -,104 dapat disimpulkan kedua variabel memeliki hubungan yang negatif atau tidak searah dan tingkat keeratan kedua variabel sangat lemah.

Kemudian menghitung nilai determinasi (R) untuk melihat seberapa (\%) distribusi berpikir kritis terhadap hasil belajar maka $0,104 \times 100 \%=10,4 \%$ dan sisanya sebesar $100 \%-10,4=89,6 \%$ dipengaruhi oleh faktor lain maka $\mathrm{H}_{\mathrm{a}}$ diterima dan $\mathrm{H}_{0}$ ditolak.

Setiap siswa memiliki tingkat berpikir kritis yang berbeda-beda, ada yang tinggi, sedang, bahkan rendah, apabila siswa dengan cara berpikir kritis yang tinggi akan mampu menyelesaikan, menjawab, menyebutkan, mengevaluasi dan menganalisis tentang cara memecahkan masalah dengan baik. Ciri seseorang mampu berpikir kritis (cricital thinking) adalah selalu mempertanyakan suatu argumen untuk memperoleh kebenaran yang hakiki (Pujiono, 2012).

Salah satu faktor penentu berhasilnya siswa dalam proses pembelajaran ialah factor internal atau faktor yang berasal dari dalam diri siswa itu sendiri seperti berpikr kritis. Siswa dengan kategori berpikir kritis yang tinggi cenderung mempengaruhi pada proses belajar yang dialaminya. Berpikir kritis merupakan proses terorganisasi yang melibatkan aktivitas mental, diantaranya menganalisis asumsi, memunculkan inkuiri biologi, dan pengambilan keputusan (Nurmaliah, 2009).

\section{Analisis hubungan bahan ajar ebook berbasis android dan berpikir kritis dengan hasil belajar}

Besar hubungan anatara bahan ajar ebook berbasis android dan berpikir kritis dengan hasil belajar secara bersama-sama dapat di lihat pada Tabel 8 di bawah ini.

Tabel 8. Analisis Hipotesis Ketiga

\begin{tabular}{|c|c|c|c|c|}
\hline \multicolumn{5}{|c|}{ Correlations } \\
\hline & \multicolumn{2}{|c|}{ Control Variables } & Ebook & Berpikir Kritis \\
\hline \multirow{6}{*}{$\begin{array}{l}\text { Hasil } \\
\text { Belajar }\end{array}$} & \multirow[t]{3}{*}{ Ebook } & Correlation & 1000 & .971 \\
\hline & & Significance (2-tailed) & . & .000 \\
\hline & & Df & 0 & 19 \\
\hline & \multirow{3}{*}{$\begin{array}{l}\text { Berpikir } \\
\text { Kritis }\end{array}$} & Correlation & .971 & 1000 \\
\hline & & Significance (2-tailed) & .000 & \\
\hline & & $\mathrm{Df}$ & 19 & 0 \\
\hline
\end{tabular}

\section{Sumber Data: Data Primer}

Berdasarkan hasil analisis hipotesis ketiga, yaitu uji korelasi ganda pada Tabel 8 hubungan antara bahan ajar ebook berbasis android dan berpikir kritis dengan hasil 
belajar konsep sistem pernapasan manusia dengan nilai correlation 0,968 dan nilai sig. 0.000 dapat disimpulkan ketiga variabel memiliki hubungan yang positif sangat kuat dan sangat signifikan. Selanjutnya menghitung nilai determinasi (R) untuk melihat seberapa (\%) sumbangsi bahan ajar ebook berbasis android dan berpikir terhadap hasil belajar konsep sistem pernapasan manusia $0,971 \times 100 \%=97,1 \%$ dan sisanya $100 \%-97,1 \%=2,9 \%$ yang dipengaruhi oleh faktor-faktor lain yang tidak diteliti, maka $\mathrm{H}_{a}$ diterima dan $\mathrm{H}_{0}$ ditolak.

Diantara bahan ajar ebook berbasis android, berpikir kritis dengan hasil belajar terdapat interaksi. Interaksi yang terjadi dipengaruhi dengan adanya bahan ajar ebook berbasis android yang menampilkan isi atau konten suatu konsep, yaitu konsep sistem pernapasan manusia yang dirancang dengan maksud dapat memberikan dampak yang positif terhadap berpikir kritis, sehingga siswa mampu dalam menjawab atau menyelesaikan pertanyaan-pertanyaan dengan baik dan mengakibatkan terjadinya peningkatan pada hasil belajar siswa.

Hasil penelitian menunjukan adanya hubungan yang sangat positif antara variabel bahan ajar ebook berbasis android dan berpikir kritis terhadap hasil belajar. Terlihat bahan ajar dapat menumbuhkan terjadinya rasa keingin tahuan dengan cara berpikir kritis sehingga terjadi perubahan peningkatan pada hasil belajar konsep sistem pernapasan manusia siswa kelas VIII SMP Negeri 3 Bula. Ukuran keberhasilan adalah sejauh mana siswa dapat menguasai materi pembelajaran dan siswa dapat mengungkapnya kembali apa yang dipelajarinya (Sanjaya, 2011). Hal ini ditekankan pada hasil belajar yang diperoleh siswa setelah proses belajar mengajar di dalam kelas melalui tes tertulis.

\section{SIMPULAN}

Berdasarkan hasil peneltian dan uji hipotesis hubungan bahan ajar ebook berbasis android dan berpikir kritis terhadap hasil belajar konsep sistem pernapasan manusia siswa kelas VIII SMP Negeri 3 Bula, maka dapat disimpulkan bahwa:

1. Adanya hubungan antara Bahan ajar Ebook berbasis android terhadap hasil belajar terlihat nilai correlation coeffecient -,145 maka, dapat disimpulkan kedua variabel memiliki hubungan yang negatif sangat lemah. Bahan ajar ebook berbasis android memberikan kontribusi sebesar 14,5\% dan sisanya sebesar $85,5 \%$ berasal dari faktor lain.

2. Adanya hubungan antara berpikir kritis terhadap hasil belajar dengan correlation coeffecient -,104, maka dapat disimpulkan kedua variabel memeliki hubungan yang negatif sangat lemah. Berpikir kritis berkontribusi terhadap hasil belajar sebesar 10,4\% dan sisanya sebesar $89,6 \%$ berasal dari faktor lain.

3. Terdapat hubungan antara Bahan ajar Ebook berbasis android dan berpikir kritis terhadap hasil belajar. Ketiga variabel memiliki hubungan positif yang sangat kuat dan sangat signifikan secara bersama-sama dengan nilai korelasi sebesar 0,971. Kontribusi yang diberikan bahan ajar ebook berbasis android dan berbikir kritis terhadap hasil belajar konsep sistem penapasan manusia sebesar $97,1 \%$ dan sisanya sebesar $2,9 \%$ berasal dari faktor lain yang tidak diteliti.

\section{DAFTAR PUSTAKA}

Depdiknas. 2003. Undang-Undang Sistem Pendidikan Nasional. (Online) http://www.inherentdikti.net/files/sisdikn as.pdf, diakses 22 Februari 2014.

Drouin, M., Hile R, E., Vartanian, L.R \& Webb, J. 2013. Student Preferences for Online Lecture Formats: Does Prior Experience Matter, the Quarterly Review of Distance.

Fikri, N. 2011. Posisi Pendidikan Indonesia Di Mata Dunia. Artikel Pendidikan (Online)

(http://nurulfikrrsda.blogspot.com/2011/ 10/posisi-pendidikan-indonesia-di-

mata.html, diakses tanggal 17 Maret 2014)

Nurmaliah, C. 2009. Kemampuan berpikir Kritis, Metakognisi dan hasil Belajar Biologi Pesertadidik SMP Negeri di Kota Malang Disertasi Tidak diterbitkan Malang: Program Pasca Sarjana Pendidikan Biologi UM. 
Biopendix, Volume 6, Nomor 2, Pebruari 2020, hlm. 109-116

Pujiono, S. 2012. Berpikir Berpikir Kritisdalam Literasi Membaca dan Menulis untuk Memperkuat Jati Diri Bangsa. PIBSI XXXIV Tahun 2012, UNSOED.

Sanjaya, W. 2011. Pengertian Prestasi Belajar. Jakarta: Kencana Prenada Media Group.

Sukmadinata, N. S. 2009. Landasan Psikologi Proses Pendidikan. Bandung: PT Remaja Rosdakarya.
Sugiyono. 2010. Metode Penelitian Kuantitatif Kualitatif dan R\&D Bandung: Alfabeta.

Sugiyono. 2012. Metode Penelitian Kualitatif dan R \& D Bandung: CV. Alfabeta.

Usman, M. U. 2000. Menjadi Guru Profesional. Bandung: Remaja Rosdakarya. 